AGH DRILLING, OIL, GAS • Vol. 35 • No. 1 • 2018

http://dx.doi.org/10.7494/drill.2018.35.1.201

\author{
Jacek Dudek*, Damian Janiga*, Paweł Wojnarowski*
}

\title{
THE MODEL OF DEVELOPMENT \\ OF THE MULTIHORIZONTAL, HYDROCARBON RESERVOIR USING ADVANCED EXPLOITATION METHODS**
}

\section{INTRODUCTION}

Over the past 20 years the world's number of large, conventional hydrocarbon reservoirs, especially those easy in exploration and development dramatically decrease. Unfortunately, in Poland there is observed similar trend, since the major discoveries in the Polish Low Lands that took place in the first years of the twenty-first century there were no significant exploration success [12]. Nonetheless, the Carpathian Foreland is still considered to be a prospective region, especially with the use of the new seismic and exploration methods [13]. Therefore, more emphasis should be placed on implementation into upstream segment the latest technologies, which enable better recognition of geological structures, accurate well placement and selection of appropriate field development strategy that gives the highest possible hydrocarbon recovery rates. The profit of most up-to-date solutions on conventional reservoirs is primarily aimed at better use of resources that have been already recognized and developed. Their scope includes both works connected with the conversion of existing vertical wells into horizontal or multilateral and using of production intensification methods or the enhanced oil recovery methods (EOR) [16].

* AGH University of Science and Technology, Faculty of Drilling, Oil and Gas, Krakow, Poland

** The research leading to these results has received funding from the Polish-Norwegian Research Programme operated by the National Centre for Research and Development under the Norwegian Financial Mechanism 2009-2014 in the frame of Project Contract no. Pol-Nor/235294/99/2014 and statutory works AGH University of Science and Technology, Faculty of Drilling, Oil and Gas no. 11.11 .190 .555 
According to advanced directional drilling techniques with real time geosteering, drilling even the most complex multilateral wells are possible [21]. Multilateral wells solutions are using particularly in most complicated reservoirs due to both the complex geological structure and the reservoir condition, in which the extraordinary precision and the maximizing of contact with the production zone are crucial. Moreover, new possibility for taking advantage of multilateral well technology without taking any excessive costs called as the slimehole drilling was carried out [8].

Unfortunately, the current situation on the petroleum market does not favor development of advanced and simultaneously expensive exploitation methods, because project profitability is strictly related to crude oil price [7]. In order to maximizing financial assets, reduce expenditure costs and provide sustainable development, EOR methods can be successfully developed and utilized. One of the world most common solutions is the application of the EOR- $\mathrm{CO}_{2}$ method in depleted or mature hydrocarbon fields, what allows for the improvement of hydrocarbon recovery factor and the underground storage of greenhouse gas.

In this paper, implementation model of multilateral slimhole wells with EOR-CO methods was presented. Furthermore, the effectiveness of proposed solution was presented based on ten years production forecasts which are performed on the full scale, compositional, reservoir model of the matured hydrocarbon reservoir located in Polish Carpathian Foredeep.

\section{THE DESCRIPTION OF THE DYNAMIC RESERVOIR MODEL}

Based on the full scale static model of multilayered hydrocarbon reservoir situated in the south of Poland, the authors created the dynamic model of hydrocarbon reservoir. The main hydrocarbon accumulation is bedded in the Second Ciężkowice Sandstones - Eocene, in the Upper Istebna Beds. All of the productive horizons are interbedded by impermeable shale layers. Therefore taking into consideration their depths there were distinguished the following layers:

- A, B - the Paleocene and the Down Istebna Beds.

- C-I, C-II, C-III, C-IV, C-V, D and E - the Upper Cretaceous.

Moreover, each horizon is split by longitudinal and transverse faults, dividing model into 55 isolated regions without any hydraulic connection, which considered regions are presented in Figure 1.

Analysis of drilling and production data from different regions reveals reservoir complexity in term of fluid PVT properties and phase behavior [10]. Among analyzed horizons, one phase (oil or gas) as well as two-phase (oil with gas cap) region occurred (presented in Fig. 2), thus fluid model were carefully created to mimic actual field state. 


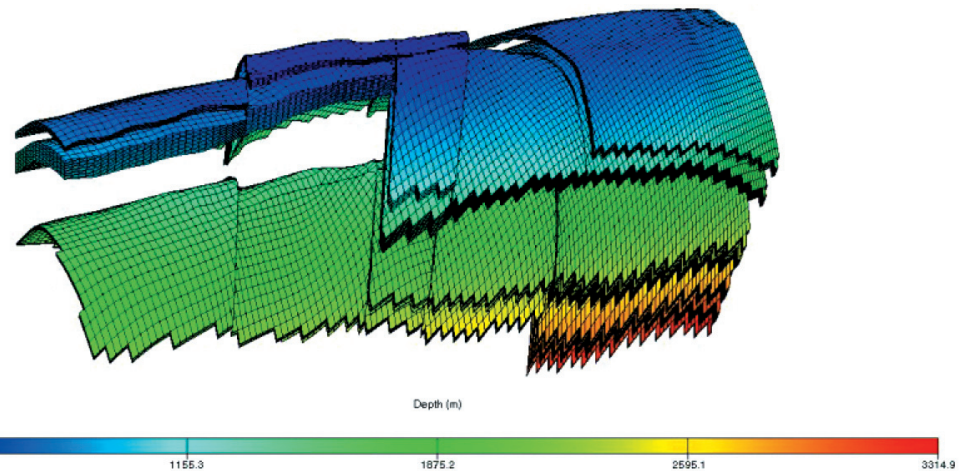

Fig. 1. The visualization of the hydrocarbon reservoir after excluding of inactive regions

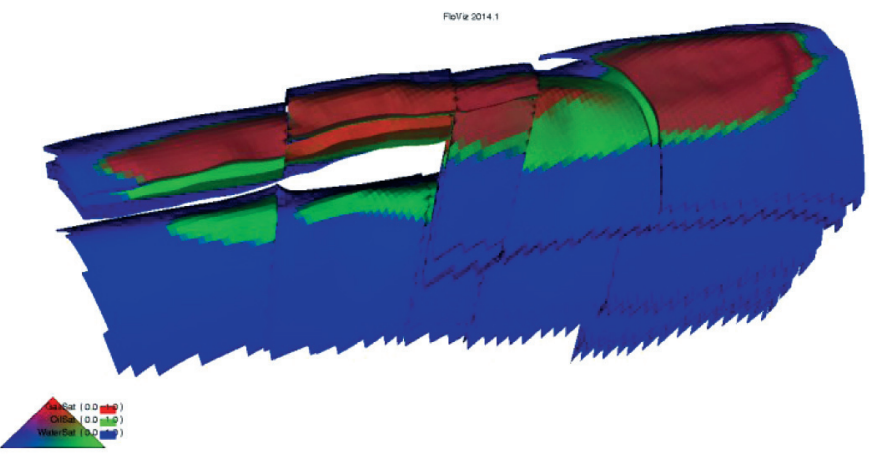

Fig. 2. The visualization of three phase saturation - oil (green), gas (red) and water (blue)

The final step of performing the dynamic simulation model was conducting of proper reservoir calibration in which the process of history matching for the period from 1976 to 2017 has been completed. The final parameters of the calibrated, dynamic model were presented in the Table 1 .

\section{Table 1}

The reservoir parameters after the calibration process

\begin{tabular}{|l|c|}
\hline Average pore pressure PV [bar] & 130.77 \\
\hline Average reservoir pressure in horizon A-B [bar] & 69.84 \\
\hline Average reservoir pressure in horizon C-I [bar] & 220.45 \\
\hline Average horizontal permeability [mD] & 6.11 \\
\hline Average vertical permeability [mD] & 3.06 \\
\hline Average porosity factor [-] & 0.022 \\
\hline Average cell size Dx, Dy [m] & 9.44 \\
\hline
\end{tabular}




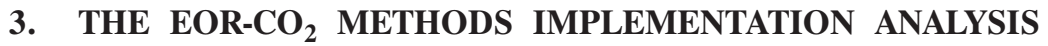

\subsection{Characterization of EOR- $\mathrm{CO}_{2}$ methods}

The carbon dioxide can be successfully stored in depleted as well as matured hydrocarbon reservoirs. Moreover, $\mathrm{CO}_{2}$ can be successfully implemented in EOR method, however some additional requirements must be fulfilled when extension from simple storage are considered [9].

Because of low average recovery factor (around 30\%) of oil reservoirs, improved oil production that stems from EOR methods can significantly enhance the oil recovery indicator. The injected $\mathrm{CO}_{2}$ forms in reservoir three different phases; mobile, residual and dissolved in oil. In addition, in the case of long-term $\mathrm{CO}_{2}$ sequestration, it is important to consider the physical and geochemical processes taking place in the reservoir [11].

The most common EOR- $\mathrm{CO}_{2}$ method in oil and gas industry is the hydrocarbon drainage through the mixing of injected gas with reservoir fluid (Fig. 3).

Nonetheless, screening criteria are used to determine suitable reservoir for $\mathrm{CO}_{2}$-EOR process implementation. The minimal required reservoir parameters for miscible $\mathrm{CO}_{2}$-EOR project were listed in the Table 2.

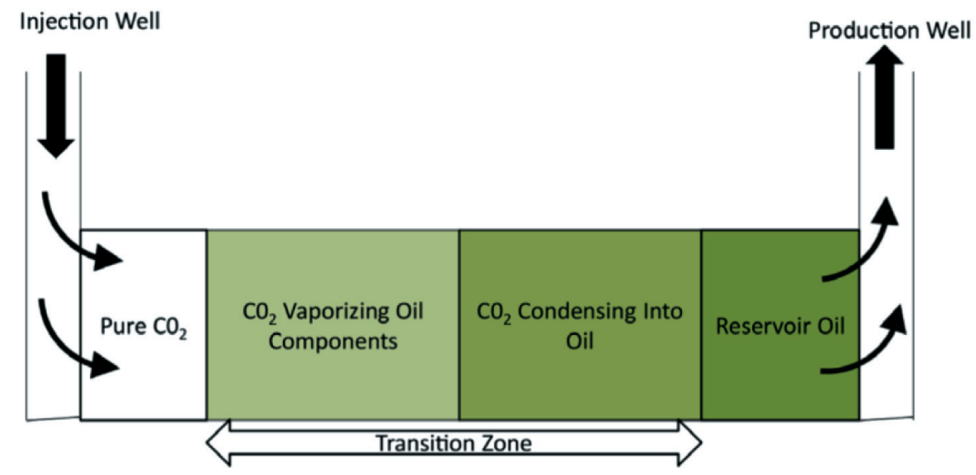

Fig. 3. The schematic of the miscible EOR- $\mathrm{CO}_{2}$ process showing the transition zone [6]

Table 2

The principal, reservoir requirements for using miscible $\mathrm{EOR}-\mathrm{CO}_{2}[9]$

\begin{tabular}{|l|c|}
\hline Depth $[\mathrm{m}]$ & $>610$ \\
\hline Temperature $\left[{ }^{\circ} \mathrm{C}\right]$ & $28-121$ \\
\hline Pressure & $>$ MMP and $<$ Pf \\
\hline Porosity [\%] & $\geq 3$ \\
\hline Permeability [mD] & $27-45$ \\
\hline Oil density [API] & $<6$ \\
\hline Oil viscosity [mPa·s] & $\geq 30$ \\
\hline Oil remaining in reservoir $[\%]$ & \\
\hline
\end{tabular}




\subsection{Implementation of EOR- $\mathrm{CO}_{2}$ methods into dynamic simulation}

In order to increase oil recovery factor and storage efficiency of carbon dioxide, comprehensive project of $\mathrm{CO}_{2}$ injection were carried out.

Stage 1. The typing of proper layers that will be able to safety injection of $\mathrm{CO}_{2}$.

Because of shallow localizations $(<600 \mathrm{~m})$, large number of old-drilled wells which can be prone to leakage, the PC-II horizon was excluded. Moreover, due to uncertainty connected with reservoir parameters of the horizons C-IV, C-V, D-I, authors suggested to omit pointed horizons from further investigation. Therefore, the productive of $\mathrm{CO}_{2}$ injection the A-B (Fig. 4) and C-I (Fig. 5) horizons were taken under consideration.

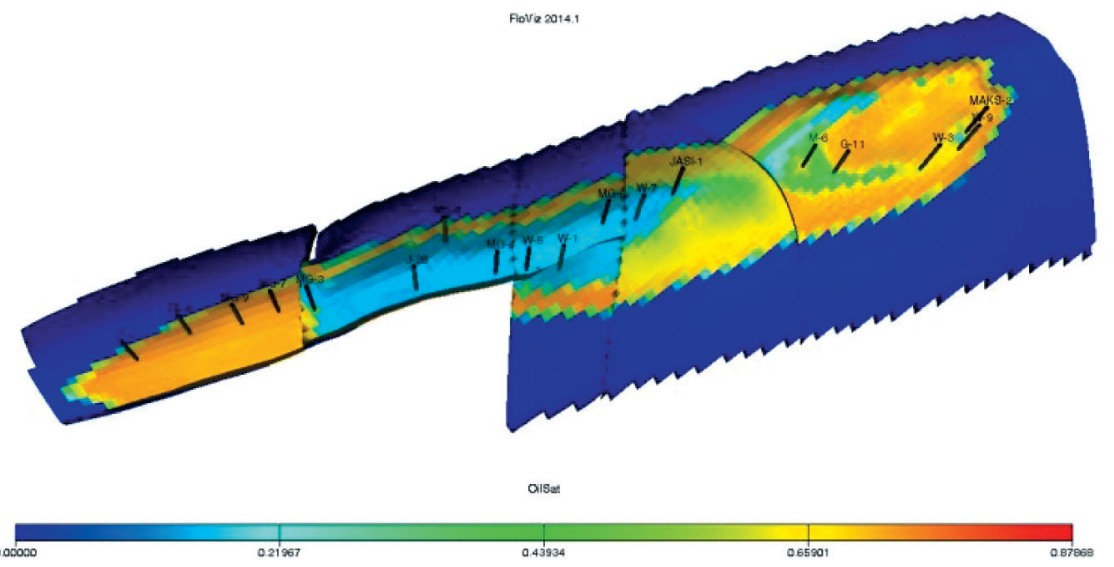

Fig. 4. Oil saturation of A-B horizon in 2016

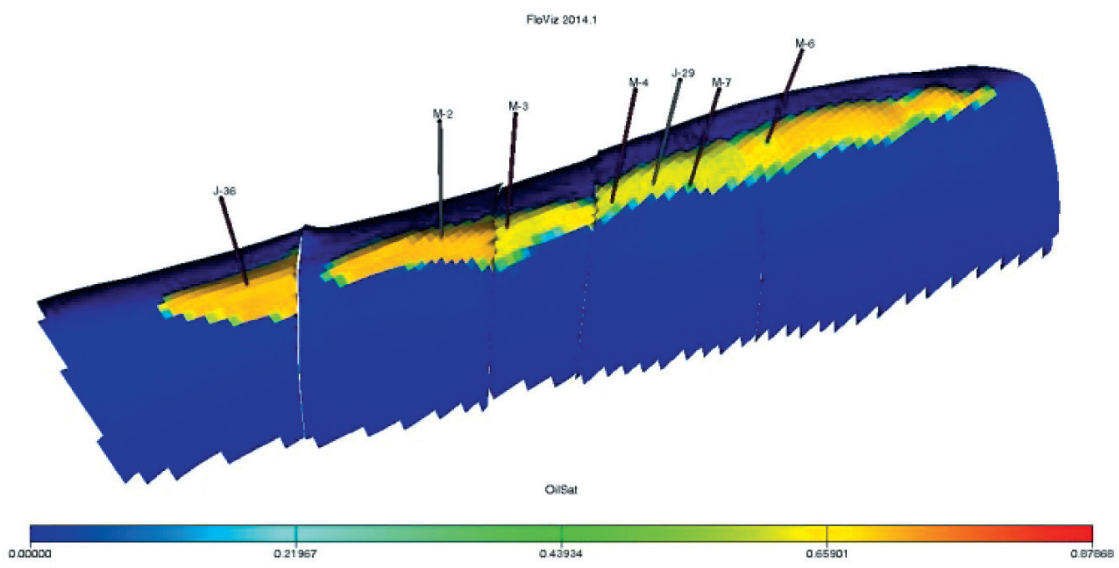

Fig. 5. Oil saturation of $\mathrm{C}$ horizon in 2016 
The consecutive problem demanding the detailed analysis is the amount of drilled wells in the A-B horizon. Therefore, before the beginning of injection the examination of casing condition of existing wells must be performed [5]. In the case of any signs of damaged casing of abandoned wells, the storage horizons should be additionally isolated, since the increase of pressure in a given region may lead to the squeeze of the pipes and thus the eruption of the reservoir fluid to the surface.

\section{Stage 2. The selection of region into which the $\mathrm{CO}_{2}$ will be injected.}

The basic criterion was the capacity of individual regions and the remaining oil saturation. Based on such assumption, four different regions were selected from both A-B and C-I production horizons.

\section{Stage 3. The design of planned injection wells.}

The drilling project of injection wells consists of number, localization, trajectory and completion scheme. Proposed $\mathrm{CO}_{2}$-EOR project was evaluated using five vertical wells. The wells will be located at far away from water-oil contacts in the opposite of the splitting regions faults (Fig. 6).

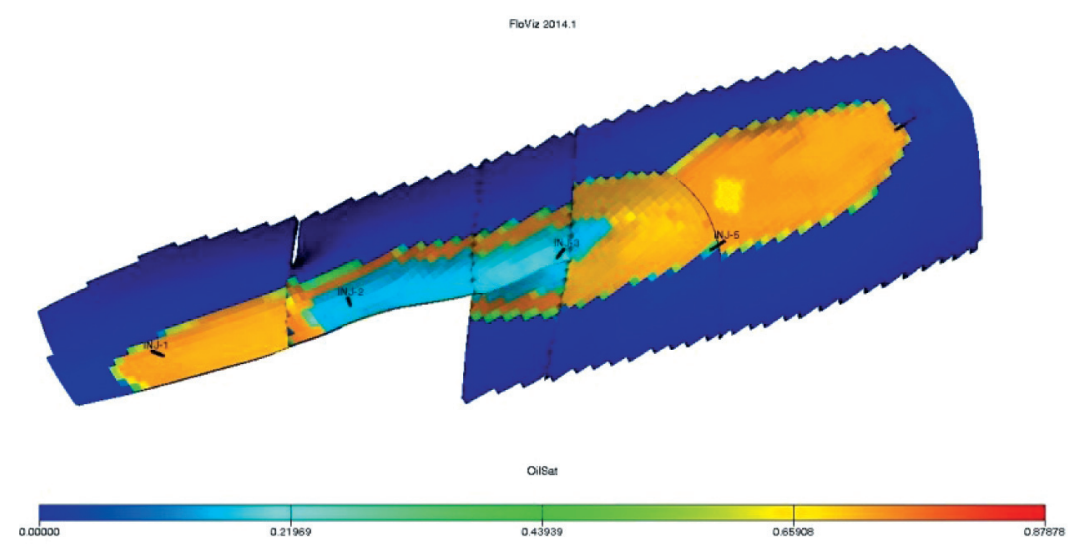

Fig. 6. The localization of injection wells on the field with oil saturation, AB horizon

Each of injection wells exposure two horizons, suitable for $\mathrm{CO}_{2}$ injection, which allows, after workovers, dual completion development of the production zone without the necessity of drilling another well. The main parameters of the designed wells were presented in Table 3. 
Table 3

The main parameters of designed injection wells

\begin{tabular}{|c|c|c|c|c|c|}
\hline Name & INJ-1 & INJ-2 & INJ-3 & INJ-4 & INJ-5 \\
\hline Type & Vertical & Vertical & Vertical & Vertical & Vertical \\
\hline Drilled regions & $27,11,3$ & $28,12,4$ & $29,15,7$ & $25,9,1$ & 26,1 \\
\hline Length [m] & 1485.4 & 1464.4 & 1442.1 & 1483.8 & 1565.2 \\
\hline Diameter [in] & $41 / 2$ & $41 / 2$ & $41 / 2$ & $41 / 2$ & $41 / 2$ \\
\hline $\begin{array}{l}\text { Bottom hole } \\
\text { temperature }[\mathrm{C}]\end{array}$ & \multicolumn{5}{|c|}{-} \\
\hline Upper horizon & 35.7 & 28.8 & 28.3 & 36.1 & 36.7 \\
\hline Lower horizon & 54.7 & 54.0 & 53.4 & 54.6 & 57.1 \\
\hline Depth & \multicolumn{5}{|c|}{-} \\
\hline Upper horizon & \multicolumn{5}{|c|}{-} \\
\hline Top [m] & 836.2 & 625.5 & 608.9 & 859.8 & 879.1 \\
\hline Bottom [m] & 970.2 & 800.4 & 768.5 & 958.7 & 967.1 \\
\hline Lower horizon & \multicolumn{5}{|c|}{-} \\
\hline Ceiling [m] & 1473.3 & 1449.9 & 1437.3 & 1468.2 & 1538.2 \\
\hline Floor [m] & 1485.4 & 1464.4 & 1442.1 & 1483.8 & 1565.2 \\
\hline
\end{tabular}

\section{Stage 4. The determination of the boundary conditions for $\mathrm{CO}_{2}$ injection.}

After the comprehensive analysis of reservoir properties as well as given production requirements, there were determined major project assumptions:

- The injection pressure must not exceed the fracturing pressure of the rock formation, therefore the bottom hole pressure was limited to the 250 bar.

- Fixed in time injection rates, ranging from $4000 \mathrm{~m}^{3} / \mathrm{d}$ to $6000 \mathrm{~m}^{3} / \mathrm{d}$ depend on well, were determined.

- The produced $\mathrm{CO}_{2}$ will be captured and reinjected to the reservoir.

- The reservoir pressure in an analyzed region cannot exceed $110 \%$ of initial value, after reach proposed limitation, the injection well will be switched over to the horizon above.

- The shutting of production well was considered when the content of $\mathrm{CO}_{2}$ will exceed $20 \%$ fraction of produced fluid.

- In order to reduce the risks connected with damaging the old wells and additional expenses bounded with $\mathrm{CO}_{2}$ separation, only two wells will be active (producer and injector) in the region in which the carbon dioxide will be injected. 


\section{THE SLIMHOLE MULTILATERAL WELLS IMPLEMENTATION ANALYSIS}

\subsection{Characterization of multilateral well technology}

The complex geological structure reduces the possibility of to increase the recovery factor using only vertical wells. In such multi-layered reservoir one of the greatest possibility of field development is drilling multilateral wells which maximally increase the contact between pay zones and wellbore, reaching the zones with the highest crude oil saturation.

Multilateral wells are able to simultaneously achieve several production horizons in the most even geologically complex reservoirs. Generally, these boreholes consist of the main trunk (stem), junction (branching), laterals (legs) and the parts of the well that leave the lateral at a right angle called the branch or curved called splay [14]. The principal construction elements of multilateral wells were presented in Figure 7.

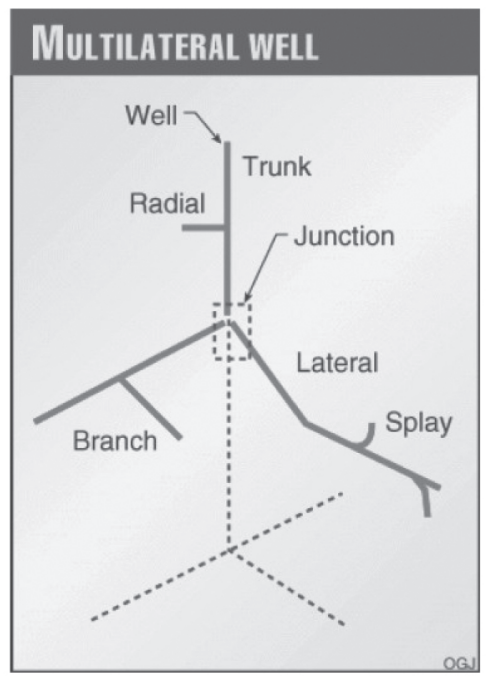

Fig. 7. The outline of the multilateral well construction [3]

One of the greatest drawbacks of using multilateral wells are its costs, which depending on the degree of well complexity for one junction ranges from $20000 \$$ to over 1000000 \$ [3]. Therefore, more and more popular conception becomes the idea of the slimhole drilling. It is an inexact term describing a borehole (and associated casing program) significantly smaller than a standard approach, commonly a wellbore less than 6 in diameter. The slimhole work involves using more or less conventional equipment and procedures, but simply reducing hole and casing sizes for each well interval [4]. 
Below there are highlighted the main advantages of slimhole technology [8]:

- Reduction of drilling costs by $30-50 \%$ - smaller drilling crews, faster drilling process.

- The possibility of obtaining a large amount of geological data using the method continuous coring.

- The possibility of relatively cheap redevelopment of matured hydrocarbon reservoirs and underground gas storages.

- Better accuracy of drilling because of using geosteering.

- More environmentally friendly technologies; smaller consumption of pipes, washers, cement, etc.

- The possibility of using multi-level holes for operation of several production horizons.

Currently, the most popular slimhole drilling methods is the coiled tubing (CT). Basically, it is use of a flexible steel pipe at the same time performing the function of drill string and mud line as well as control line [1]. CT pipes with 1-3 1/2" diameter are used for drilling, which allow making holes up to $81 / 2^{\prime \prime}$ diameter [8]. One of the greatest advantage of $\mathrm{CT}$ is they proficiency in the matured field in order to reconstruction of old wells, in which can be drilled the new directional, horizontal or even multilateral part. Therefore, such facility appears to be extremely interesting for Polish oil and gas field, especially those multilayered as the reservoirs of Polish Carpathian Foredeep.

\subsection{Implementation of multilateral well technology into dynamic simulation}

\section{Stage 1. Selection of regions, which will be developed by multilateral wells.}

The basic criterion was the capacity of individual regions and the remaining oil saturation. Based on such assumption, four different regions were selected from both A-B and C-I production horizons

\section{Stage 2. Designing of multilateral wells construction.}

Considered wells consist of two branches emerging from a stem in the A-B horizon and a horizontal part in the C-I horizon with sufficient distance from existing wells. Additionally at a distance of about $2 \mathrm{~m}$ from the end of tubing, there were designed perforations of the casing pipes that connect the wells with the reservoir. Initially the project of multilateral well with completion was presented in Figure 8. 


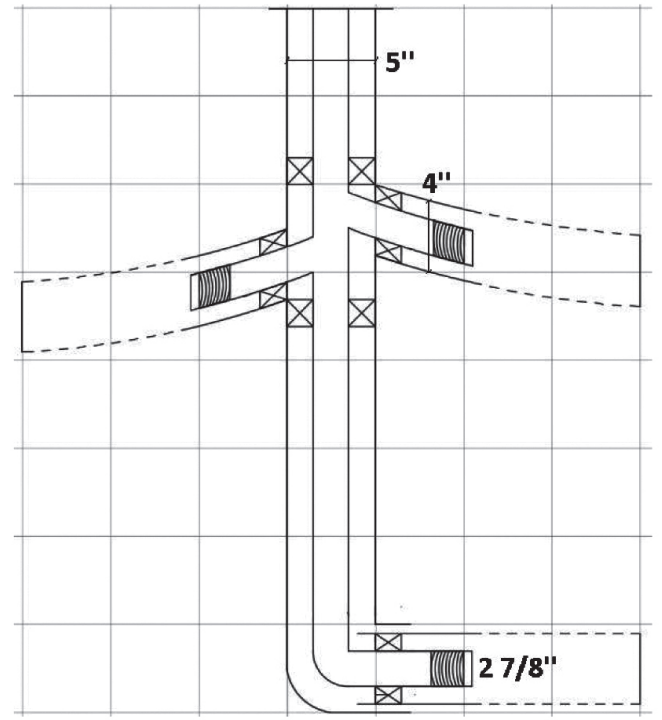

Fig. 8. The construction of planned multilateral well with completion

Subsequently, based on the created scheme, the construction of multilateral wells was built in 3D technology, presented in Figure 9, using the Schedule program included in the Schlumberger Eclipse software package. In addition, trajectories of individual wells have been adapted to provide access to specific reservoirs zones.

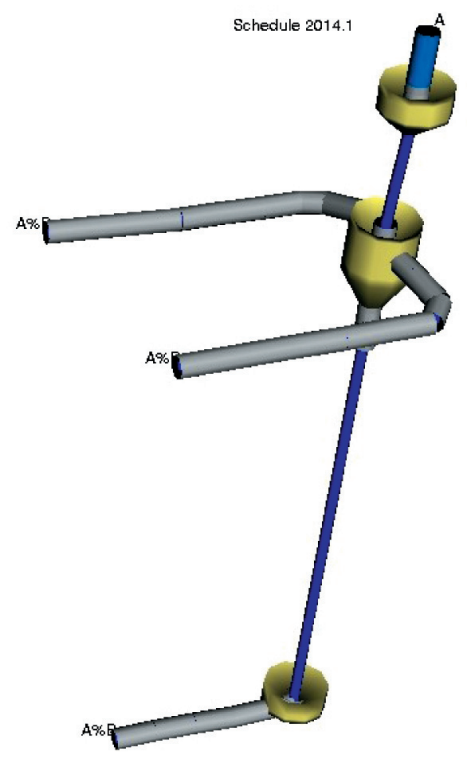

Fig. 9. The three dimensional project of multilateral well construction made in Schedule 


\section{Stage 3. The adjustment of well trajectory.}

Based on conducted analysis of the regional oil saturation distribution and the localization of existing vertical wells, multilateral wells trajectory were developed and implemented in 3D reservoir model (Fig. 10 and 11).

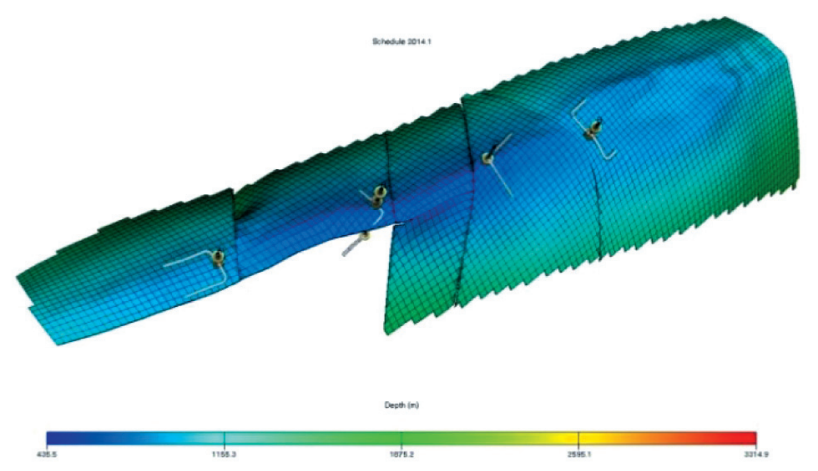

Fig. 10. The visualization of designed well trajectory in production horizon $A B$

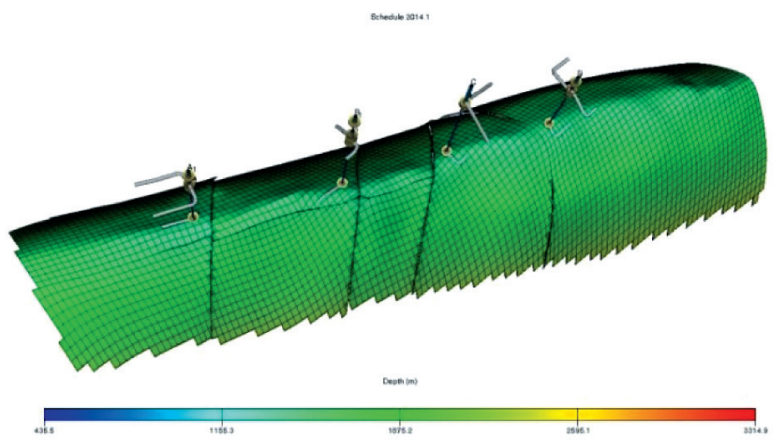

Fig. 11. The visualization of designed well trajectory in production horizon C-I

\section{RESULTS}

\subsection{Production forecast}

In order to examine the effectiveness of proposed solutions there were performed five ten-year's production forecasts with assumptions defined in the previous chapters, which covered the following scenario of field development:

- Scenario A (base): Standard production - no drilling of any new wells, existing wells will continue production with the last historical rates. 
- Scenario B: Production with multilateral wells - drilling four multilateral wells, existing wells will continue production with the last historical rates.

- Scenario C: Multilateral wells production - drilling four multilateral wells, all of existing vertical wells will be shut.

- Scenario D: Production with EOR-CO $\mathrm{CO}_{2}$ methods - five injection wells will be drilled and each of them will develop two different regions, existing wells will continue production with the last historical rates.

- Scenario E: Multilateral wells with $\mathrm{EOR}-\mathrm{CO}_{2}$ methods - five injection wells and four multilateral wells will be drilled and each of them will develop two different regions, all of existing wells, expect one, will be shut.

In Figures 12-14 results of ten years production forecasts were presented.

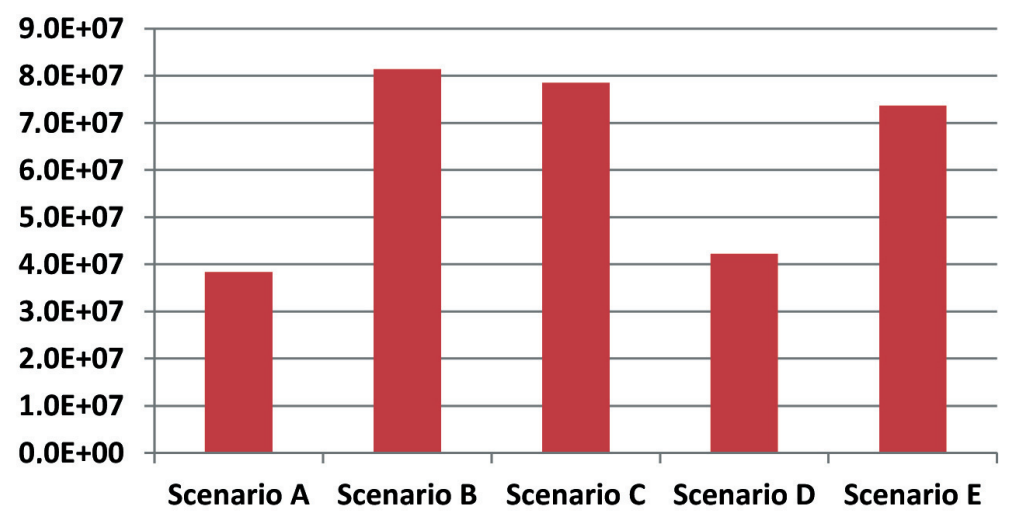

Fig. 12. Ten years forecast of total field gas production $\left[\mathrm{m}^{3}\right]$

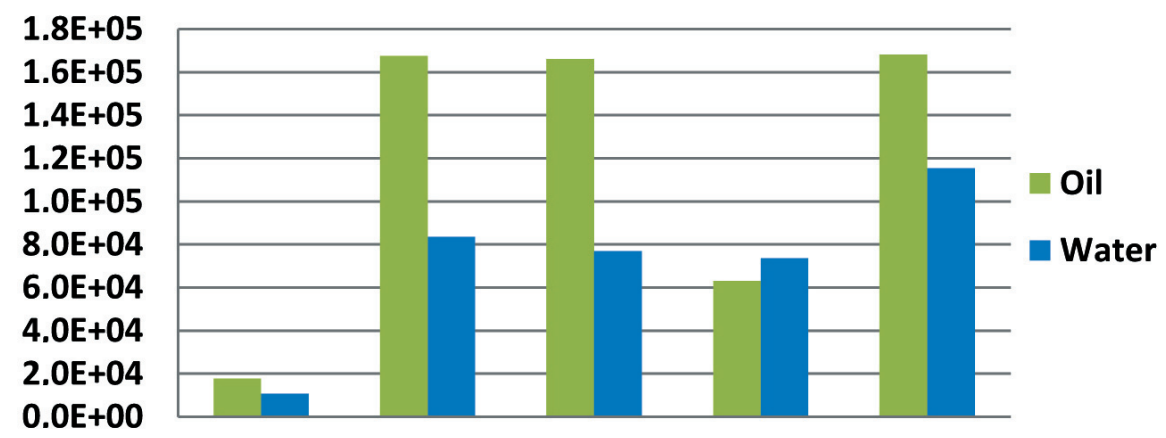

Scenario A Scenario B Scenario C Scenario D Scenario E

Fig. 13. Ten years forecast of total field oil and water production $\left[\mathrm{m}^{3}\right]$ 


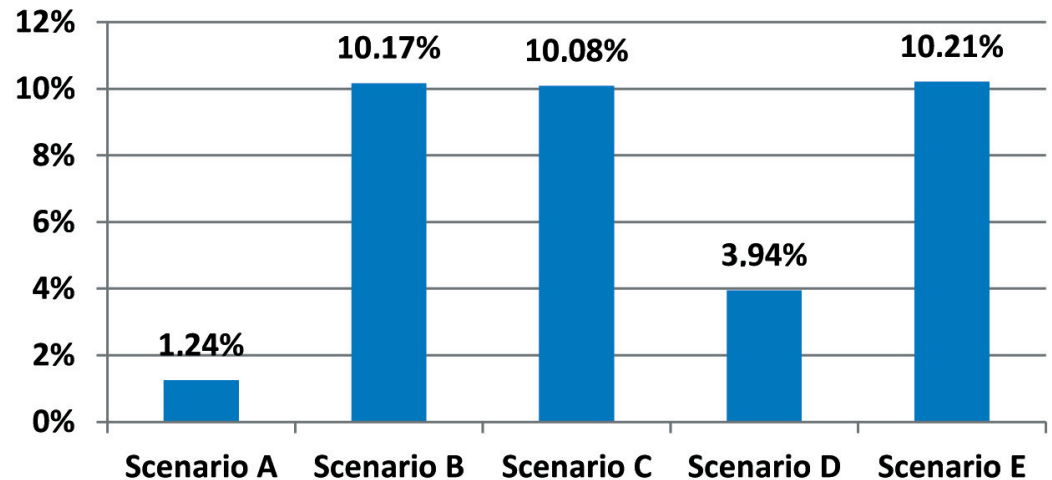

Fig. 14. Ten years forecast of recovery factor increase

According to the data presented in the Figures 12-14 the maintenance of current production will provide only about $1 \%$ of additional recovery factor. Scenario D, which assumes implementation of $\mathrm{EOR}-\mathrm{CO}_{2}$, provides almost fourfold production increase with simultaneously seven times greater water production. Furthermore, it can be clearly seen that the greatest degree of hydrocarbon exploitation was obtained by the scenarios $\mathrm{B}, \mathrm{C}$ and $\mathrm{E}$. Those forecasts assume the reservoir development using multilateral well and improving of recovery factor of over $10 \%$. Nonetheless, in scenario $\mathrm{E}$ the greatest growth of total hydrocarbon recovery was connected with over $30 \%$ higher water production, what assuming costs of brine utilization considerably decrease project income. In spite of the fact that B and C scenarios present similar result, scenario B assumes the work of all wells, what can bring additional operational cost. To sum up, basing on obtained results the scenario $\mathrm{C}$ was considered as the most profitable.

\subsection{Carbon dioxide issue}

On the other hand, Figure 15 shows the amount of injected carbon dioxide. The scenario E, which uses the multilateral wells with $E O R-\mathrm{CO}_{2}$ presents over $10 \mathrm{MMm}^{3}$ greater $\mathrm{CO}_{2}$ reservoir capacity than the case D assuming development with vertical wells.

Apart from the increment in crude oil and $\mathrm{CO}_{2}$ production and costs of surface installation, depending on the initial assumptions linked with the local policy the volume of pumped carbon dioxide can be treated as financial burden or additional profit, therefore the role of carbon dioxide may completely change entire economic model.

Furthermore, because of increasing amount of $\mathrm{CO}_{2}$ in reservoir the quality of produced gas constantly decrease. As can be clearly seen in Figure 16 the composition of produced gas varies significantly within production period. 


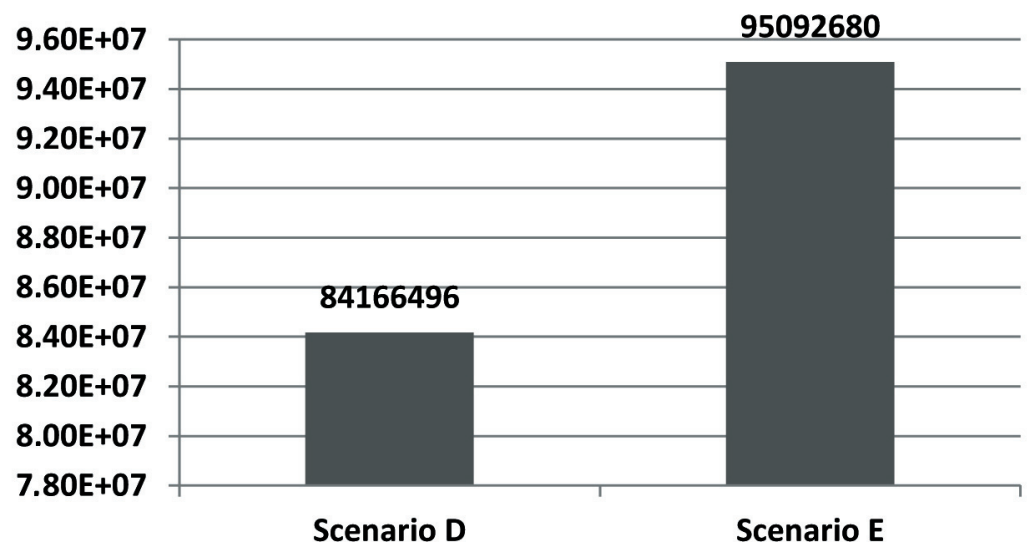

Fig. 15. Ten years forecast of total injected carbon dioxide $\left[\mathrm{m}^{3}\right]$

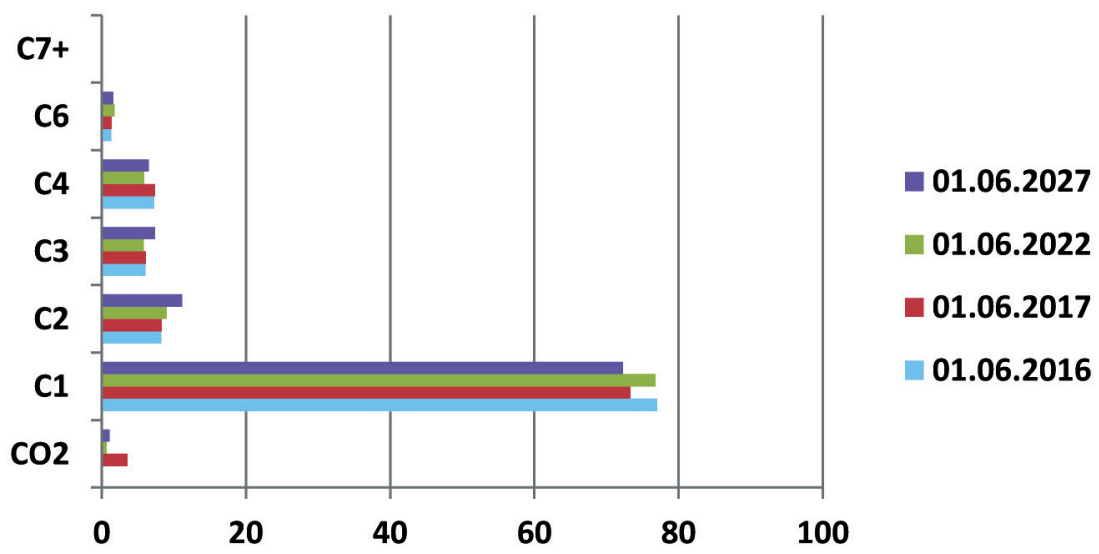

Fig. 16. The change in the produced gas composition for Scenario E

Because of adopted boundary condition all of the wells/branches are shut when the fraction of $\mathrm{CO}_{2}$ in produced gas exceed the value of 0.2 what explain the decrease in $\mathrm{CO}_{2}$ share at the end of the production forecast. Moreover, the majority of produced carbon dioxide is captured and reinjected into reservoir, therefore the surface facilities must be able to cope with changing composition of produced fluid.

According to the data presented in Figure 14 the implementation of EOR-CO methods, depending on scenario increased the ultimate recovery factor of around $4-10 \%$. In comparison to the data from the report of American Petroleum Institute [15] the obtained result are in the average effectiveness of using enhanced oil recovery methods connected with $\mathrm{CO}_{2}$. However, the results from the scenario $\mathrm{E}$ that brought over 
$10 \%$ of recovery factor, could be significantly improved because of using multilateral slimehole drilling not because of $\mathrm{CO}_{2}$ sequestration. Therefore, as the reliable performance indicator was chosen the result from the scenario B. Unfortunately, the improvement of around $4 \%$ is considerably below the US average $-8-20 \%$, such phenomena may arise due to complicated geological structure of reservoir.

\subsection{Simplified economic model}

In order to develop the profitability study of entire project authors performed economic analysis based on simplified cash flow function:

$$
C F=F O P T \cdot 423.87 \$+F G P T \cdot 0.098 \$-F W P T \cdot 19.38 \$-F G I T \cdot 0.073 \$
$$

where:

FOPT - cummulative oil production $\left[\mathrm{m}^{3}\right]$, price of the WTI crude oil $67,39 \$ / \mathrm{bbl}$,

$F G P R$ - cummulative gas production $\left[\mathrm{m}^{3}\right]$, price of the USA natural gas $2,735 \$ / M M b t u$,

FWPT - cummulative water production $\left[\mathrm{m}^{3}\right]$,

FGIT - cummulative $\mathrm{CO}_{2}$ injection $\left[\mathrm{m}^{3}\right]$.

The comparison of production forecasts $C F$ shows Figure 17.

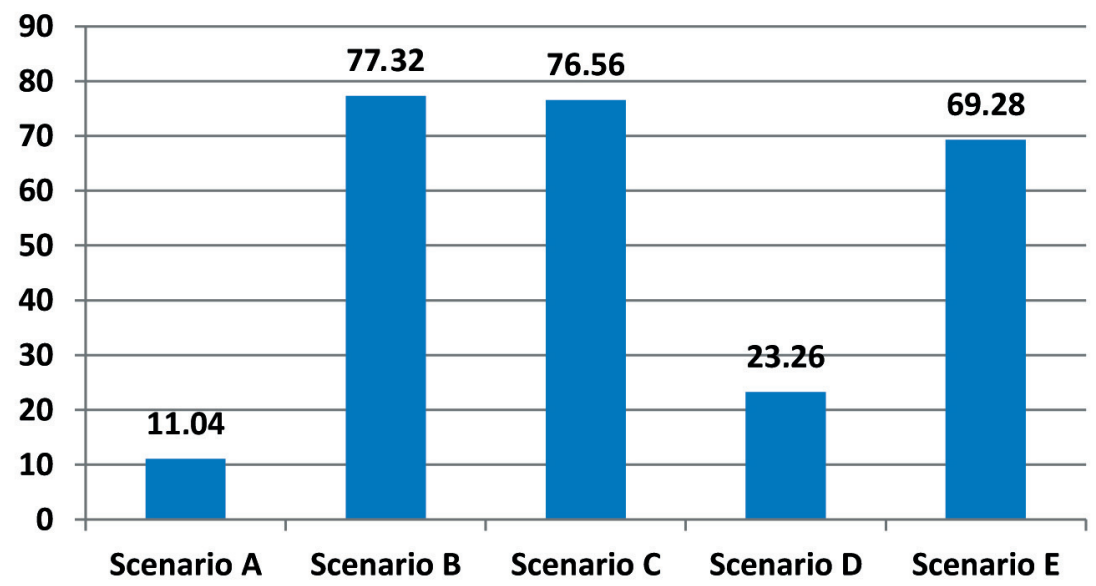

Fig. 17. The comparison of production forecasts $C F[\mathrm{MM} \$]$

Additionaly, in order to estimate the economy of planned investment there was assesed the approximation of capital and operation expenditures (Tab. 4). 


\section{Table 4}

The estimation of potential capital and operational expenditures

\begin{tabular}{|l|c|}
\hline \multicolumn{1}{|c|}{ Type of investment } & Unit cost $[\$]$ \\
\hline Iniection wells & 3000000 \\
\hline Silmhole multilateral well & 2000000 \\
\hline Surface facilities & 10000000 \\
\hline Pipeline $[\$ / \mathrm{km}]$ & 300000 \\
\hline The $\mathrm{CO}_{2}$ sequestration fee $\left[\$ / \mathrm{m}^{3}\right]$ & 0.0031 \\
\hline The crude oil exploitation $\mathrm{fee}\left[\$ / \mathrm{m}^{3}\right]$ & 13.20 \\
\hline Variable production costs $\left[\$ / \mathrm{m}^{3}\right]$ & 15.58 \\
\hline Production operation cost $[\$ /$ year $]$ & 1500000 \\
\hline Interest rate $[\%]$ & 8 \\
\hline
\end{tabular}

After substraction from the predicted profits the assumed costs associated with drilling and equipment of planned wells, operating charges and the creation of the necessary surface installations the profitability of particular scenarios may considerably change. In order to estimate the approximate $N P V$ of performed variants the following equation was used:

$$
N P V=\sum_{t=1}^{n} \frac{C F_{t}}{(1+r)^{t}}-I_{0}
$$

where:

$$
\begin{aligned}
N P V & - \text { net present value, } \\
C F_{t} & - \text { net cash flow, } \\
r & - \text { discount rate, } \\
t & - \text { time of the cash flow. } \\
I_{0} & - \text { initial investment cost. }
\end{aligned}
$$

The NPV of particular forecasts after taking into account potential capital and operational expenditures shows Figure 18.

The achieved change in projects economy presents that all of the exenditures connected with performing all of required $\mathrm{CO}_{2}$ instalation as well as with the advanced multilareal well driling are able to completely switch the profitability of the planned investment. However, for confirmation purposes, more detailed financial analisis should be performed, taking into account all costs and potential risks. 


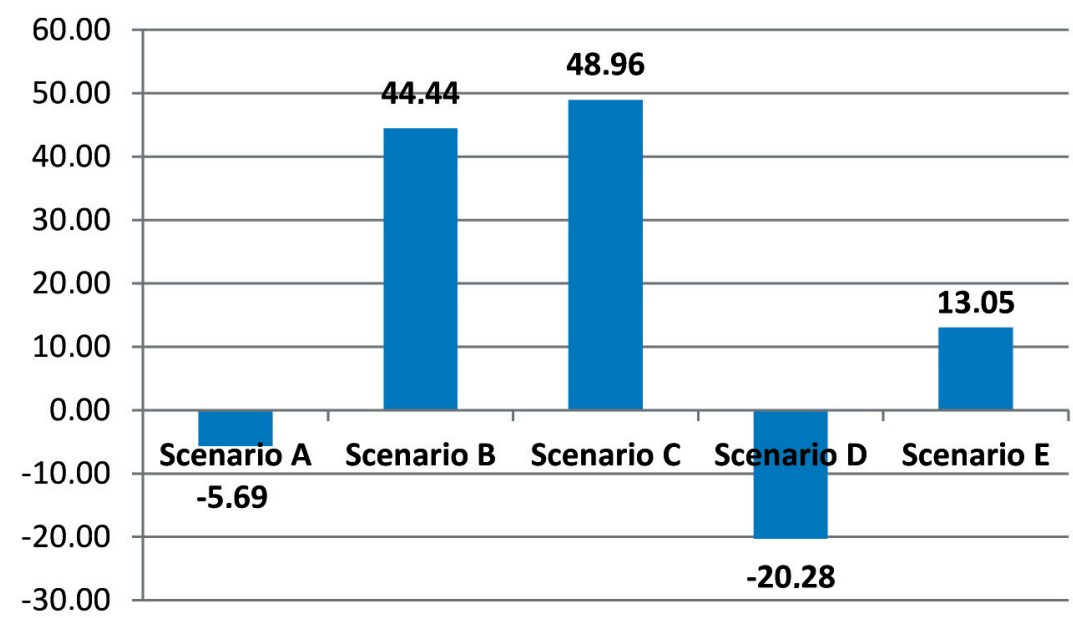

Fig. 18. The NPV of particular forecasts after taking into account potential capital and operational expenditures [MM\$]

\section{CONCLUSIONS}

In presented work authors proposed the implementation of advanced exploitation methods - silmhole multilateral well technology and EOR- $\mathrm{CO}_{2}$ into one of the polish Carpathian hydrocarbon reservoir.

Based on created full scale compositional simulation reservoir model, there were conducted and examined five different development strategies. Moreover, in order to rank the performed production forecasts there were proposed two main criterions recovery factor and estimated projects NPV. For the sake of the increment in extra hydrocarbon production the scenarios $\mathrm{B}, \mathrm{C}$ and $\mathrm{E}$ showed the greatest results. However, for the scenario $\mathrm{E}$ the excessive water production may significantly worse the production profile. Subsequently, for the scenario B can be clearly seen the less production efficiency than for scenario $\mathrm{C}$, because the production of entire field (all old wells with new multilaterals) is almost similar to those with production of only new wells, therefore the scenario $\mathrm{C}$ seems to be the most prospective. Moreover, the NPV analysis indicates that considerable costs of installation required $\mathrm{EOR}-\mathrm{CO}_{2}$ and $\mathrm{CSS}$ surfaces facilities and all of the expenses linked with production maintenance costs additionally favor the profitability of scenario $\mathrm{C}$.

Nonetheless, the final feasibility of proposed scenarios strictly depends on current situation on the crude oil market as well as on the local environmental policy that may favor or not the sequestration of carbon dioxide. Therefore any proposed advanced exploitation strategies appear to be worth considering for further implementation. 


\section{REFERENCES}

[1] Afghoul A.C., Amaravadi S., Boumali A., Calmeto J.C.N., Lima J., Lovell J., Tinkham S., Zemlak K., Staal T.: Coiled Tubing: The Next Generation. Oilfield Review, Schlumberger, vol. 16, iss. 1, 2014, pp. 38-57.

[2] Gantt L.L., Leising L., Stagg T., Walker R.: Coiled tubing drilling on the Alaskan North Slope. Oilfield Review, vol. 10, iss. 2, 1998, pp. 20-35.

[3] Hill A.D., Zhu D., Economides M.J.: Multilateral Wells. Society of Petroleum Engineers, 2008.

[4] http://www.glossary.oilfield.slb.com/Terms/s/slim_hole_well.aspx [access: 26.04.2018].

[5] Janiga D., Wojnarowski P., Czarnota R.: Technical conditions of well application for EOR-CCS project in Polish conditions. SGEM2015 Conference Proceedings, June 18-24, 2015, Book 1, vol. 1, pp. 821-826.

[6] Jarrell P.M., Fox C.E., Stein M.H., Webb S.L.: Practical aspects of $\mathrm{CO}_{2}$ flooding: Richardson, Tex.. Society of Petroleum Engineers Monograph Series, vol. 22, 2002, 220 p.

[7] Kosowski P., Rychlicki S. (Ed.), Stopa J., Wojnarowski P.: Wtórne i trzecie metody wydobycia ropy naftowej (EOR). Możliwości zwiększenia efektywności wydobycia ropy naftowej ze złóż karpackich. Wydawnictwa AGH, Kraków 2010, pp. 71-116.

[8] Miziołek M.: Wiercenia otworów typu slim hole na świecie i możliwości zastosowania ich na obszarze zapadliska przedkarpackiego i Karpat. Nafta-Gaz, nr 12, 2014, pp. 905-917.

[9] Núñez-López V., Holtz M.H., Wood D.J., Ambrose W.A., Hovorka S.D.: Quicklook assessment to identify optimal $\mathrm{CO}_{2}$ EOR storage sites. Environmental Geology, 54(8), 2008, pp. 1695-1706.

[10] Plezia B.: Dodatek nr 4 do Dokumentacji geologicznej złoża ropy naftowej i gazu ziemnego Jaszczew. Jasło 1996.

[11] Pooladi-Darvish M., Hong H., Theys S., Stocker R., Bachu S., Dashtgard S.: $\mathrm{CO}_{2}$ injection for enhanced gas recovery and geological storage of $\mathrm{CO}_{2}$ in the Long Coulee Glauconite F Pool, Alberta. SPE Paper 115789, 2008.

[12] Rychlicki S., Stopa J.: Directions of Development of Polish Gas and Oil Field. AGH Drilling, Oil, Gas, vol. 33, no. 2, 2016, pp. 237-243.

[13] Rychlicki S.: Możliwości zwiększenia efektywności wydobycia ropy naftowej ze złóż karpackich. Wydawnictwa AGH, Kraków 2010.

[14] Stopa J., Rychlicki S., Wojnarowski P.: Zastosowanie odwiertów multilateralnych na złożach ropy naftowej w późnej fazie eksploatacji. Wiertnictwo Nafta Gaz, t. 24, 2007, pp. 495-501.

[15] Meyer J.P.: Summary of Carbon Dioxide Enhanced Oil Recovery (CO $\mathrm{C}_{2} \mathrm{OOR}$ ) Injection Well Technology. American Petroleum Institute.

[16] Wojnarowski P., Stopa J., Janiga D., Kosowki P.: Możliwości zwiększenia wydobycia ropy naftowej $w$ Polsce z zastosowaniem zaawansowanych technologii. Polityka Energetyczna, t. 18, z. 4, 2015, pp. 19-28. 